\title{
Coptic Modifications in the Tombs of Beni Hassan
}

\author{
Sara Isaac, Youssri Abdelwahed, Eltayeb Abbas
}

Tourist Guidance Department, Faculty of Tourism and Hotels, Minia University

\begin{abstract}
This article deals with Coptic modifications in the Pharaonic tombs at Beni Hassan, which were converted into Christian structures. The total number of the converted tombs at Beni Hassan is 10 . These tombs originally date back to the Middle Kingdom (the 11th and 12th dynasties). These tombs were reused by the early Christians during the fourth century $\mathrm{AD}$. Some of the tombs were transformed into educational places, while others were converted into churches or habitats.
\end{abstract}

\section{Introduction:}

The early Christians dealt with pagan monuments in two ways. In some cases, they destroyed pagan monuments as they did in the case of many temples and statuary. In other cases, they simply converted pagan structures into Christian buildings, notably churches, teaching schools, and residential spaces. In the latter, they had to make numerous necessary architectural alternations in order to fit their needs. ${ }^{1}$

In the fourth century AD, the weakness of the political role of the Roman emperor allowed both the senators and the bishop to become public figures of importance. In the mid-fourth century AD, the bishop of Rome was able to play a significant role in Roman politics and society, and to compete with senators for worldly status. It is from the fifth till the sixth century AD that the bishop began to get the upper hand in his competition. ${ }^{2}$ In AD 378, the heathenism, which means the peasant religion because it had almost entirely died out in the cities, was designated for the first time as paganism. On the other hand, Christianity was first referred to as the religion of slaves, because in Rome many of the oldest and most respectable families for along time still adhered to the pagan traditions. The capital city appears to have preserved until the latter part of the $4^{\text {th }}$ century hundred and fifty two temples and hundred and eighty three smaller chapels and altars of pagan patron deities. ${ }^{3}$

\footnotetext{
${ }^{1}$ Pagoulatos (without date): 1.

${ }^{2}$ Chennault 2008: 8.

${ }^{3}$ Schaff 1889: 39 .
} 
In $\mathrm{AD} 380$, the majority of the populace of the Roman Empire belonged to the Christian church. There were occasional acts of violence by Christians who destroyed buildings and images and by both pagans and Christians who committed acts of murder and intimidation. ${ }^{4}$ The destruction of ancient pagan buildings and the conversion of ancient temples and tombs into Christian churches and secular structures in the late Roman Empire during the fourth up into the sixth centuries characterize the Christian attitude towards pagan religion and civilization. They reflect the struggle of the newly established Christian empire between two cultural elements, Christianity and paganism and the combination of the two. ${ }^{5}$

In many instances, specific narrative of conversion can be identified, such as the Christianization of the ankh which occurred with the destruction of the Alexandrian Serapeum. Other practices such as the dedication of lamps were so fundamental to the idea of worship; they were ubiquitous in both paganism and Christianity. ${ }^{6}$ The Agustin, a Christian bishop in Antioch, states that "let us first obliterate the idols in the hearts of the heathen and once they become Christians they will either themselves invite us to the execution of the destruction of the idols". ${ }^{7}$ At least 10 ancient Egyptian tombs at Beni Hassan were reused by the early Christians, who made different architectural, mural, and textual modifications, which I will discuss in this article.

\section{Architectural Modifications}

\section{The wall niches}

Out of the 10 converted tombs which I have examined, only 4 tombs (the tombs of Khenomhetep II, Baqt I, Khety No. 17, and tomb No. 29) have wall niches, which were made by the early Christians. These wall niches take the shape of a square or a semicircle. The wall niches sometimes used to have a shelf, probably for holding the holy books. ${ }^{8}$ They were also used for utilitarian purposes, like storing the liturgical vessels and or holding lamps. At a later date, all niches were widened and some other simpler niches were added for domestic use, perhaps as stables as suggested by the holes in the walls intended for ropes to tether animals, other holes could have served to divide the space into smaller units. ${ }^{9}$

\footnotetext{
${ }^{4}$ Kreider 2007: 126.

${ }^{5}$ Pagoulatos (without date): 1.

${ }^{6}$ Weaverdyck 2007: 16.

${ }^{7}$ Schaff 1889: 41.

${ }^{8}$ Pyke 2009: 1 .

${ }^{9}$ Grossmann 1980:188-189.
} 
At Beni Hassan, four tombs have wall niches as one of the architectural markers of their conversion into Christian places of worship or habitat. Each tomb has more than a wall niche, always located on the south wall of the tomb. The main reason for carving all the niches at Beni Hassan on the south wall of the tombs cannot be identified with certainty. It is also unclear whether this was a deliberate choice of the individuals responsible for the transformation of these tombs. The absence of architectural precision seems to suggest that those who carved these wall niches were not professional architects. By contrast, the awkward contour of the wall niches suggest that these wall niches were carved at the hands of the worshippers or the residents of the converted tombs themselves without the help of specialized craftsmen.

The niches were de facto carved within the ancient Egyptian representational program, distorting in most cases the narrative of the Pharaonic subjects drawn on the wall. For example, the wall niche on the south wall of the tomb of Khnumhotep II is executed in a way that cut across the legs of the individuals depicted on the wall. Its measured $20 \times 20 \mathrm{~cm}$ (fig. 1) also this tomb had two wall niches take shape of semi circular each one of them executed the legs of individual (fig. 2).

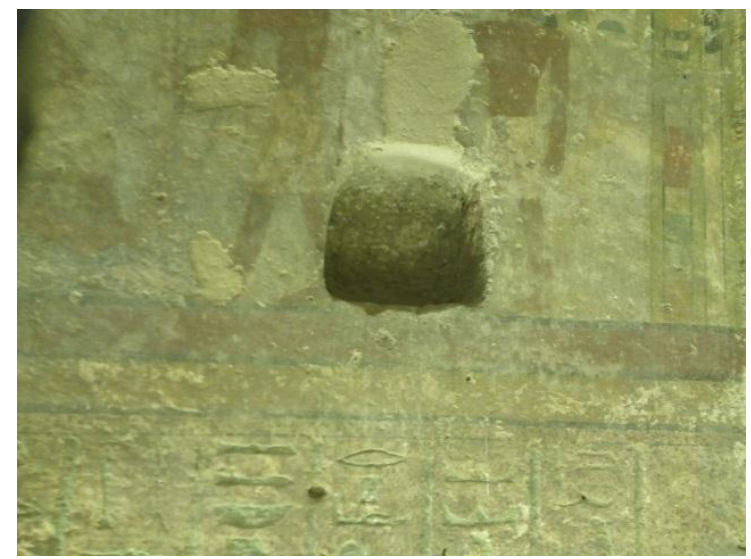

Figure 1. The wall niche in the Tomb of Khnumhotep II at Beni Hassan. 


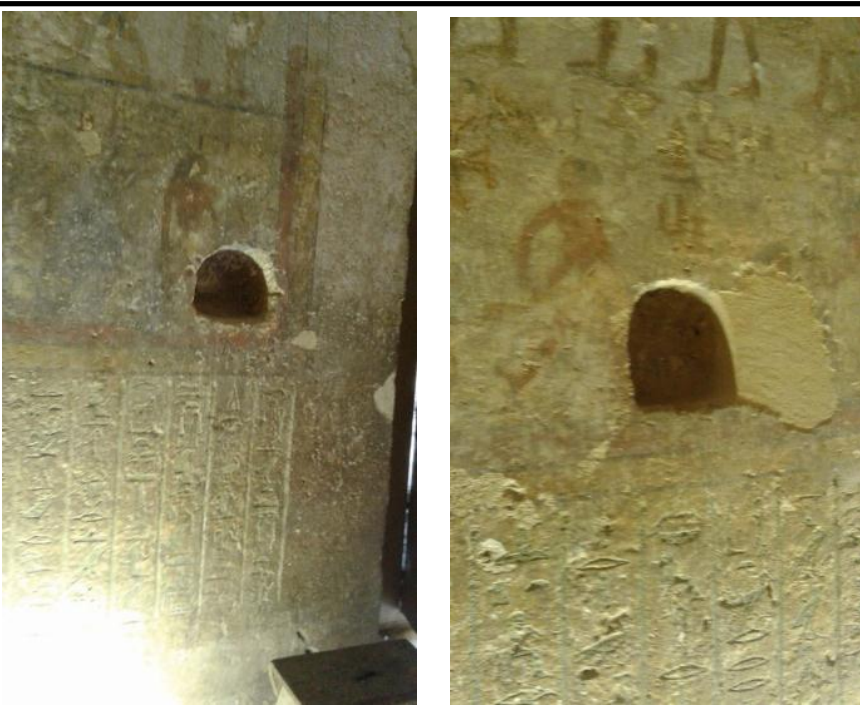

Figure 2. The wall niches in the tomb of Khenumhotep II at Beni Hassan.

On the other hand, the wall niche in the tomb of Baqt I, which is carved in the middle of the south wall, distorts central parts of the lower two registers (fig. 3). This can also be noticed in the wall niche in Tomb No. 29 at Beni Hassan, which cuts the lower register, it is measured $100 \times 60 \mathrm{~cm}$ (fig. 4). All in all, the intentional decision to carve the wall niches without paying attention to the Pharaonic representational repertoire indicates that the early Christians, who were responsible for the transformation of ancient Egyptian tombs, did not respect the earlier Egyptian iconography. This should come as no surprise given the long history of hatred and struggle between paganism and Christianity.

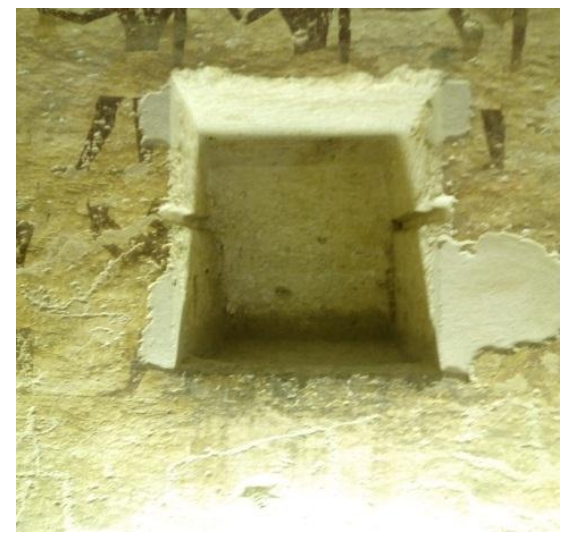

Figure 3. The wall niche in the tomb of Baqt I (No. 15) at Beni Hassan. 


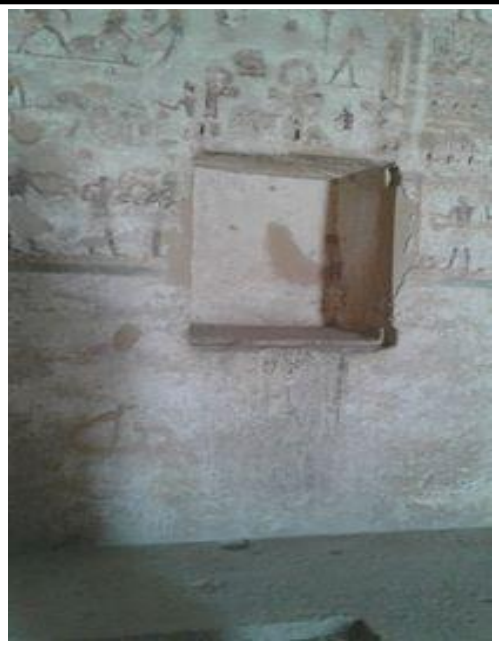

Figure 4. The wall niche in Tomb No. 29 at Beni Hassan.

Three wall niches a Beni Hassan lack decorations in the interior. The only example which has an Ankh sign on top of it is the wall niche in Tomb No. 29 which measured $100 \times 100 \mathrm{~cm}$. The cross takes the form of an ankh sign. The ankh is an ancient Egyptian sign of life in hieroglyphic transmitted to the Christian Egyptians as the cross or sign of eternal life. It has a rounded head and it was always carried by the gods of Egyptian mythology as well as the Pharaohs, who were regarded as gods and found in ancient Egyptian art as the child god Horus wearing a chain with cross around his neck in the early Christian period the ankh was automatically adopted as cross. ${ }^{10}$ This type of ankh-shaped cross is frequently found in later Coptic art, it is better known as the Egyptian cross. The upper element of the ancient Egyptian ankh symbol is elongated, while that of the $a n k h$-shaped cross is circular. ${ }^{11}$ When one looks at the top of the wall niche in tomb no. 29 (fig. 4), there is a clear $a n k h$-shaped cross. 


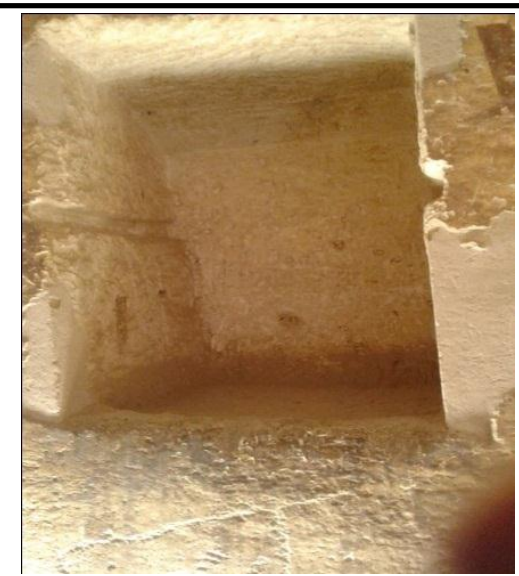

Figure 5. The wall niche in the tomb of Khety (Tomb No. 17) at Beni Hassan.

The wall niche in the tomb of Khety (Tomb No. 17), which is carved in the middle of the south wall, takes shape of a square, but it is deeper than the other wall niches at Beni Hassan. It was carefully cut. It is noteworthy that there is an incision on either side of the wall niche approximately half the height of the wall niche. Apparently, this wall incision was meant to carry a shelf, probably made out of wood or other material. The existence of a wall niche with a shelf suggests that this niche was intended to contain more objects that the non-shelf wall niches. This wall niche lacks any type decoration either in the interior or the exterior. The absence of black carbon on the ceiling of the wall niche suggests that it was never used for holding lamps (fig. 5).

\section{The Doorways}

Out of the 10 tombs which I have examined at Beni Hassan, only 4 tombs have doorways (tombs 28, 29, 32, and 33). These tombs which were converted had doorways in middle of the shared wall of the tombs to connect them. Since tomb 28 served as a church, it is likely that the early Christians carved the doorway to connect with tomb 29 to provide more space to worshippers (fig. 6). ${ }^{12}$ The carving of a doorway in the middle of the shared wall has unfortunately destroyed much of the scenes. It is noteworthy that the jambs of the doorways bear no decoration at all. Since tomb 33 was used as a teaching school, the early Christians in need of space for students carved a doorway into the shared wall with tomb $32 .{ }^{13}$ It is clear that the architecture of the tombs was not a barrier for the Christian users, who could transform the

\footnotetext{
${ }^{12}$ Newberry 1893: 34 .

${ }^{13}$ Newberry 1893:78.
} 
architecture of the rock-cut tombs to meet their religious and teaching requirements.

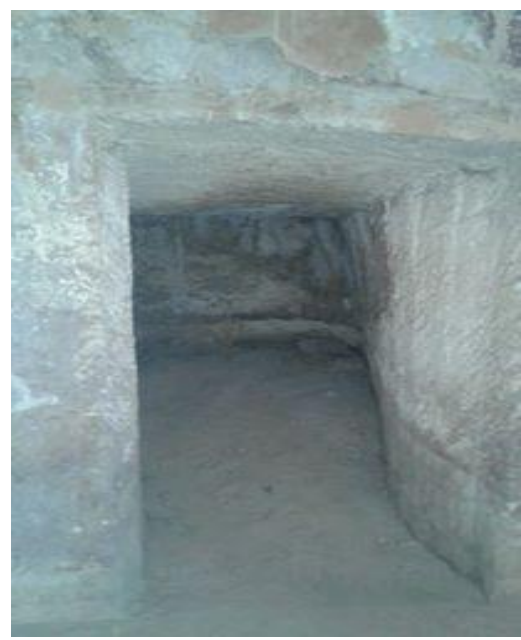

Figure 6. The doorway in tomb 29 at Beni Hassan.

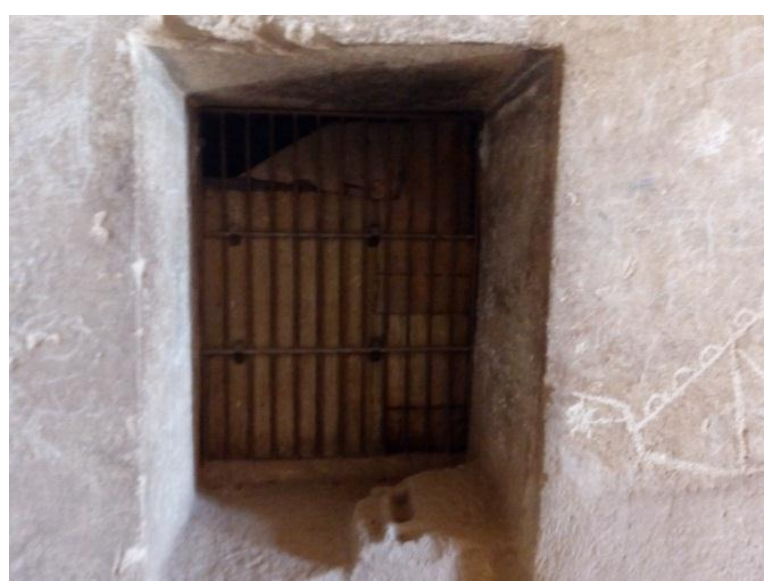

Figure 7. The doorway in tomb 29 at Beni Hassan.

\section{The Cutting Columns}

Out of 10 tombs which were converted into Christian structures at Beni Hassan, there are 2 tombs in which columns were cut for Christian use. (Tombs 15 and 18) at Beni Hassan. Only the base and the upper part of columns were cut in some tombs, while in other tombs the whole columns were totally removed to give more space and to adapt Christian religious needs. 
The column is a vertical architectural support that is circular in plan and slender. By contrast, the pillar is often rectangular and usually consists of two elements: shaft and capital. ${ }^{14}$ Most of the ancient Egyptian temples had columns, colonnades, and pillars and rarely do we find any of the old Coptic churches of Egypt without colonnades or pillars in their structure. ${ }^{15}$ The majority of the column bases and shafts and the series of Corinthian capitals which may have been taken from older buildings of the second to third centuries AD certainly prepared for the church were individual Corinthian capitals. ${ }^{16}$

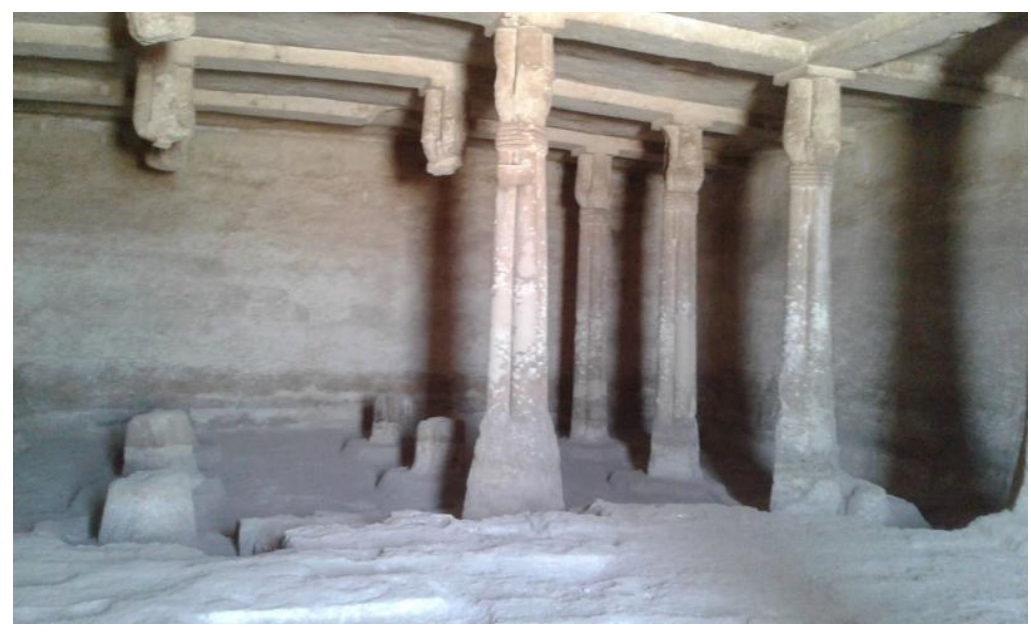

Figure 7. The columns in tomb 18 at Beni Hassan.

Tomb 18 at Beni Hassan originally had three rows of colonnades, each contains three columns. Once settled at the tomb, the early, the early Christians cut five columns out of nine, but they left the abacus, the capital, and the base in their places. Such an architectural modification was made in order to give more space (fig. 7). Another example at Beni Hassan is tomb 15, which originally had two columns. The Christians modification in this tomb included the complete removal of the abacus, capital and shaft of the two columns. Only the remains of the bases of the two columns remain in situ (fig. 8).

${ }^{14}$ Atiya 1991: 205-206.

${ }^{15}$ Yanney 1988: 109.

${ }^{16}$ Atiya 1991: 288. 


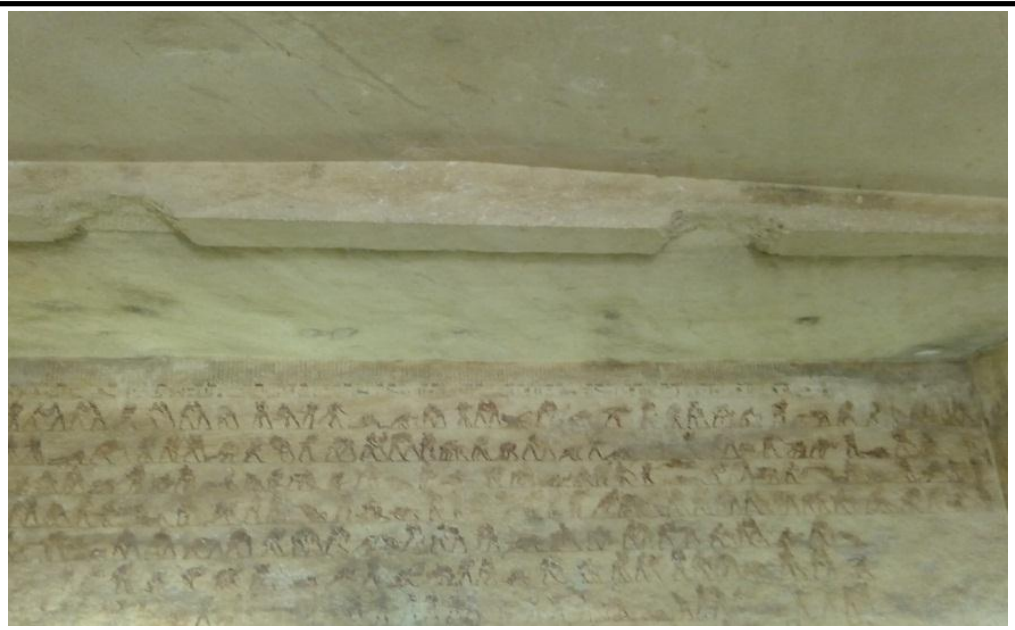

Figure 8. The cutting columns from the tomb of 15 at Beni Hassan.

The Apses

The apse is one of the most important architectural elements in Christian churches as it represents the holy of holies. The apse is always located on the innermost east wall of the church. Broadly speaking, the apse normally takes shape of a hollow niche and is often decorated with the figure of Jesus the Christ as a king holding in one hand a scepter and the globe in the other his hand and is surrounded with the angles. ${ }^{17}$ Some apses have the representations of Jesus the Christ and his mother, sometimes accompanied with angles. The cross is never carved or represented on the apses of the converted tombs at Minia. ${ }^{18}$

Only one of the converted tombs at Beni Hassan had an apse. Tomb No. 28 The apse in tomb 28 at Beni Hassan. 


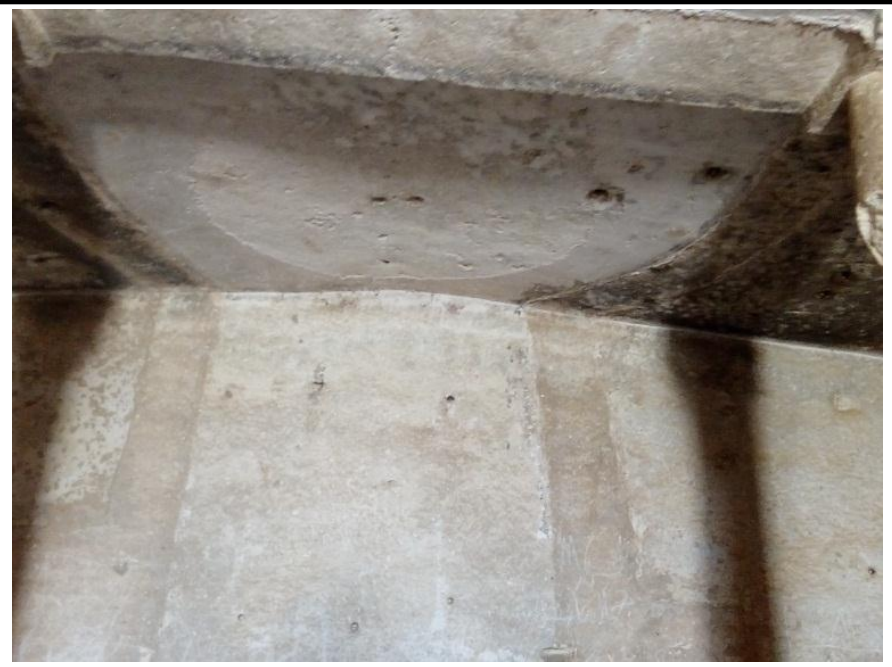

Figure 9. The apse in tomb 28 at Beni Hassan.

In tomb 28 at Beni Hassan, the Christians left the two columns of the ancient tomb to mark the apse-niche. The presence of an apse is concrete evidence that the converted tomb was once used as a church for the ceiling of the tomb and the east wall bear traces of an apse (fig. 9). It is noteworthy that the apse here is not totally hewn out of the wall of the tomb, but it is flanked by an imitation of what seem to be two columns or pillars, presumably to outline or mark the apse itself. The difference in the colors of the apse and the surrounding walls reflects that the individuals, who converted the tomb, tried to highlight the location of the apse by slightly carving it on the east wall. Surprisingly and unusually, the ceiling above the apse has a shallow semicircular hollow. Perhaps it was meant to represent a semi-dome. ${ }^{19}$ This apse lacks any decoration, suggesting that by the fourth century $\mathrm{AD}$ the custom of decorating the apses with the figure of Jesus the Christ or the accompanying angels was not yet developed or hence was not executed in the tomb of Beni Hassan. The simple design of the apse may suggest that it was carved by the hands of the residents of the tomb or the worshippers, and not by professional architects.

\section{Mural Modifications:}

Mural modifications included the plaster, black carbon, and other mural paintings, notably fishes, crosses, angles, and human figures. The Coptic graffiti consist principally of the figures and names of the trinity 
and names of saints and holy men of the Old and New Testament as well as of hermits who probably dwelt in the tombs. ${ }^{20}$

\section{The Plaster}

Plaster played an important role in fresco paintings from the second century $\mathrm{BC}$ till the second century $\mathrm{AD}{ }^{21}$ Out of the 10 converted tombs at Beni Hassan, only 2 tombs have been covered with plaster at Beni Hassan (Tombs Nos. 28 and 34). Tomb No. 28 at Beni Hassan has been covered by the Christians with Coptic plaster. Remains of the plaster can still be seen on the walls (fig. 10). ${ }^{22}$ Remains of Coptic plaster on the floor and ground can also be seen in tomb 34 at Beni Hassan; the plaster must have been added during the Coptic period by the Christians who settled in such tombs. ${ }^{23}$

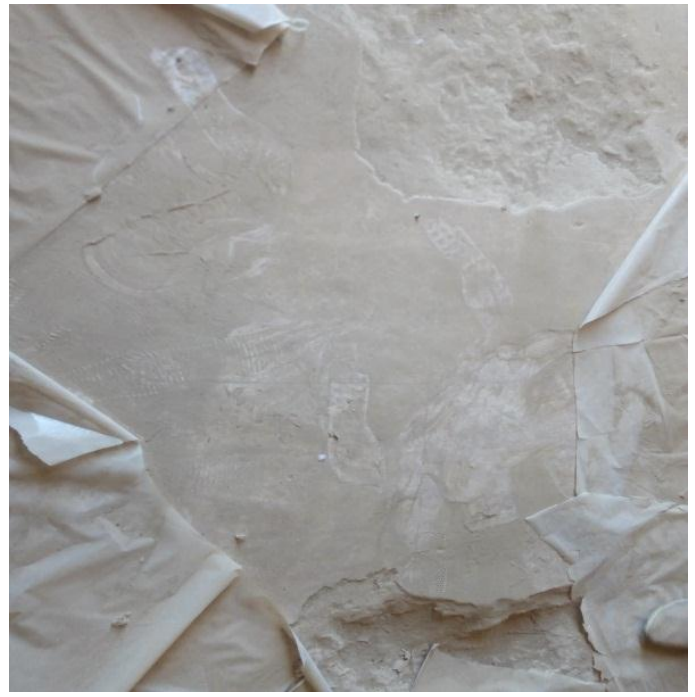

Figure 10. Remains of plaster in the ground in the tomb 28 at Beni Hassan.

\section{The Black Carbon}

Out of the 10 tombs which were converted into Christian structures, three tombs at Beni Hassan (the tombs of Amenmhat ,Khenumhotep II and tomb 23) black carbon is the outcome of the Christian use of these tombs, most probably through means of illumination or food cooking.

At Beni Hassan, one can see the black carbon on the ceiling of the tomb of Amenmhat (Tomb No. 2). The remains of black carbon

${ }^{20}$ Newberry 1893: 63.

${ }^{22}$ Newberry 1893:32.

21 قادوس 2002:

${ }^{23}$ Newberry 1893:40. 
have unfortunately caused serious damage to the decoration of the ceiling (fig. 11).

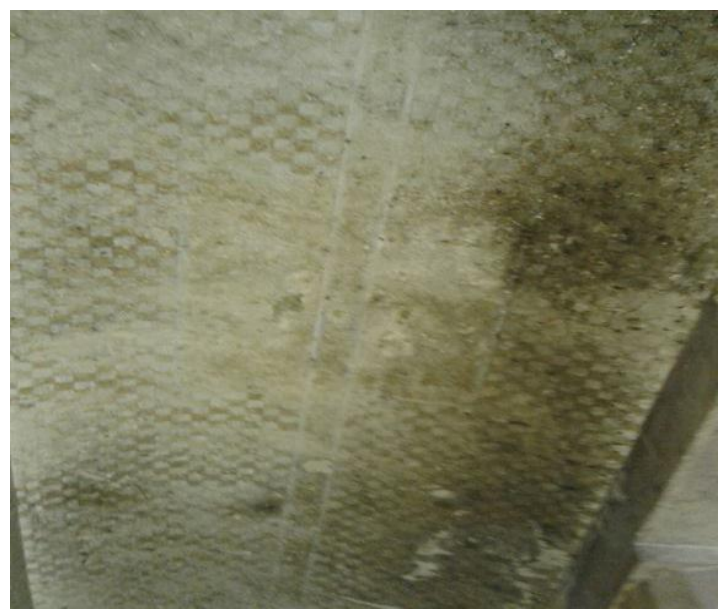

Figure 11. Black carbon on the ceiling of the tomb of Amenmhat at Beni Hassan.

The tomb of Khenumhotep II has the remains of black carbon on its ceiling and on the upper part of the walls, which were exposed to damage due to the Christian use of the tomb (fig. 12).

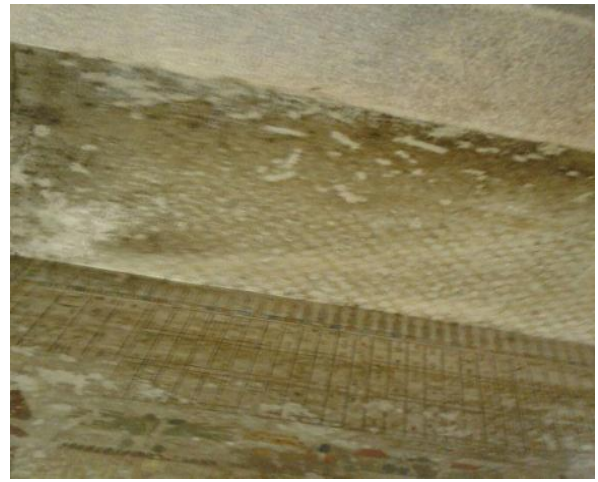

Figure 12. Black carbon on the ceiling of the tomb of Khenumhotep II at Beni Hassan.

Tomb No. 23 at Beni Hassan is the only confirmed example of the use of black carbon on the walls of the tomb due to illumination, since the early Christians have undoubtedly left two openings on the wall for holding lamps (fig. 13). 


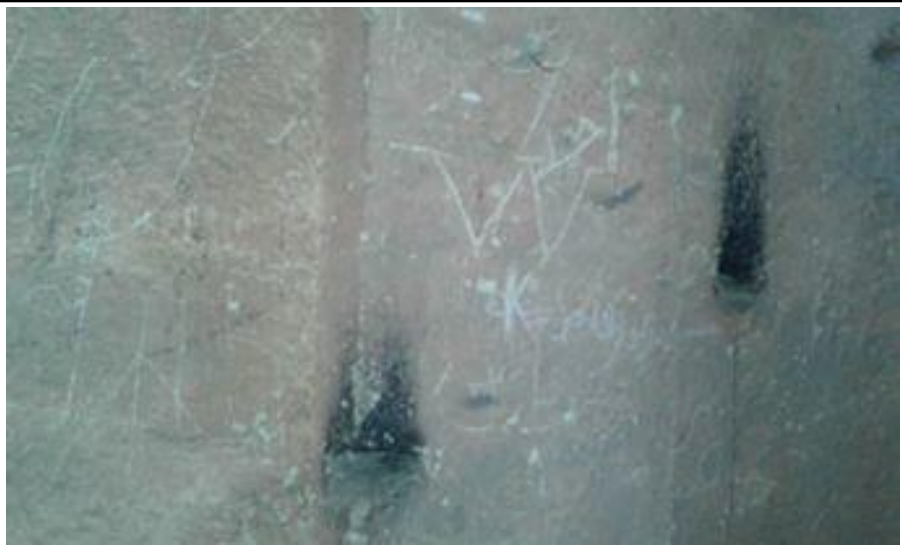

Figure 13. The black carbon in tomb No. 23 at Beni Hassan.

\section{Other Mural Paintings:}

The Fishes

The fish is the symbol of Jesus Christ; a fish is sculptured upon a number of Christian monuments and more on sarcophagi. It is also depicted on amulets suspended around the neck by children and upon ancient glasses and lamps. Moreover, the baptismal fonts is particularly associated with the fish, in Christianity found it necessary to appropriate the images of paganism and to purify them with Christian ideality some of fathers see about the fish, we are little fishes in Christ our great fish. In the middle of the fourth century Optatus, the bishop of Milesia in Africa declared that (the single name of fish according to the Greek denomination contained in the letters composing it, host of the sacred names $(i 9 \times q u / j$ ) gives in the Latin Jesus Christ, the son of god, the savior. ${ }^{24}$

Out of the 10 tombs which were converted into Christian structures, two tombs at Beni Hassan (tombs No. 18 and 23) have the decoration of fish on their walls. In tomb No. 18, the forepart of a fish is carved on the south wall of the tomb, which lacks any decoration (fig. 14). 


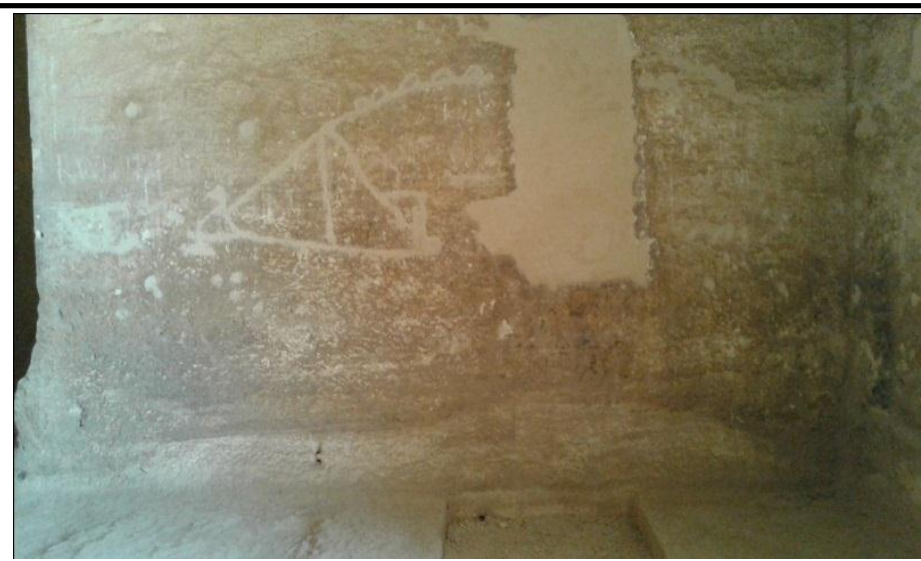

Figure 14. The picture of fish in the tomb of 18 at Beni Hassan.

In tomb No. 23 at Beni Hassan, the forepart of a fish is similarly carved on the south wall of the tomb, yet in this case the fish is accompanied with Coptic writings, which will be discussed later in this chapter (fig. $15)$.

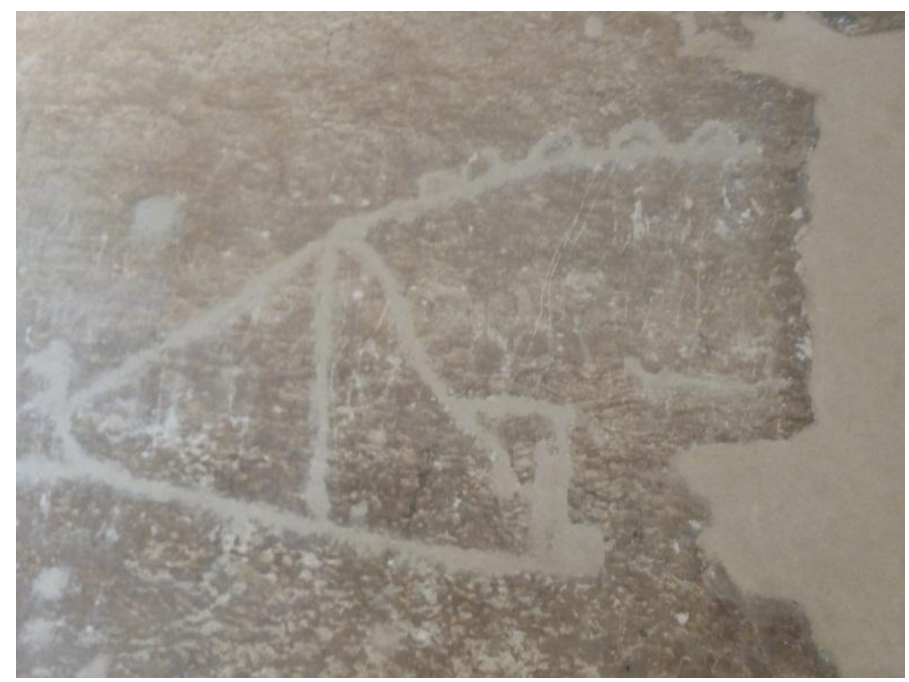

Figure 15. The fish from the tomb of 23 at Beni Hassan.

The Crosses:

The word atonement usually refers to the belief that it was death of Jesus on the cross that accomplished the taking away of sins. Hence, the cross symbolizes both human guilt and mercy god in Christian beliefs. The sign of the cross takes various forms, each having its own interpretation, it may be made with the right thumb when crossing oneself and the right forefinger when crossing other people or things it was sign of god, the forms of the cross has developed since the early 
days of Christianity. ${ }^{25}$ The world is in the form of a cross for the east shines above our heads, the north is on the right, the south at the left, and the west stretches out beneath our feet; birds that they may rise in air extend their wings in the form of a cross, men when praying or when beating aside the water while swimming assume the form of a cross; man differs from the inferior animals in his power of standing erect and extending his arms. The cross has thus been the object of worship and decoration, resembling if not equal to that offered to Christ. A number of churches have been dedicated to it under the name of the holy cross. ${ }^{26}$ Out of the 10 converted tombs there are 6 of tombs at Beni Hassan (tombs No. 2, 15, 18, 21, 23, 33), various types of crosses have been confirmed in the tombs at Beni Hassan.

\section{The Ankh-shaped Cross}

The cross takes the form of an ankh sign. This type of ankh-shaped cross is frequently found in later Coptic art, it is better known as the Egyptian cross. The upper element of the ancient Egyptian ankh symbol is elongated, while that of the ankh-shaped cross is circular. ${ }^{27}$ In tomb 18 at Beni Hassan, the early Christians left an ankh-shaped cross in the middle of the south wall, thus partly damaging the figure of the individual shown on the upper register. Here, the body of the individual seems to have been converted into the head of the ankh. As a result, the wall has suffered damage as the Christians used the scene to draw their Coptic symbol instead of covering the scene with plaster (fig. 16).

\footnotetext{
${ }^{25}$ Atiya 1991: 345.

${ }^{26}$ Millington 1851: 373.

${ }^{27}$ Khalaf 2014: 189.
} 


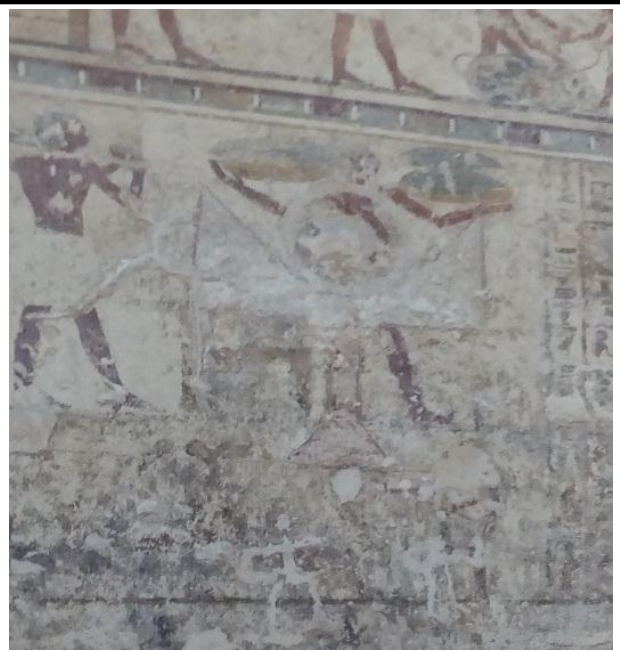

Figure 16. This ankh shape cross from the tomb 18 at Beni Hassan

The Latin or the Maltese cross

In the 10 tombs which were converted into Christian places there are four tombs which have Latin or the Maltese cross at Beni Hassan (tombs 15, 23, 33 and tomb of Khenomhotep II) .This cross is known as the Maltese cross because it is associated with the knights of Malta; it takes the form of four v-shaped elements, each joins with the others and its vertex, leaving the other two tips spread outward symmetrically. ${ }^{28}$ The cross with four equal limbs was known and adopted in the west and thus appeared on sarcophagi, columns, pillars, and altars. ${ }^{29}$ In tomb 15 at Beni Hassan, a Latin cross can be seen in the middle of the registers of the wrestling scenes. The cross has thus damaged the ancient Egyptian iconography. This is evidence for using these tombs during the imperial persecution of the Christians (fig. 17).

Another example at Beni Hassan is tomb no. 23, in which the Latin cross is completely damaged. It is painted on a wall of the tomb, which is bare of any decoration. However, we can see the remains of Coptic writings around the cross. In both tombs, the Maltese or Latin cross is drawn in red ink (fig. 18). As the red color evokes the color of blood and therefore is the color of martyrs and death of Christ on the cross also it symbolizes fire and therefore is the color of Holy Spirit. ${ }^{30}$

\footnotetext{
${ }^{28}$ Khalaf 2014: 194.

${ }^{29}$ Millington 1851: 377 .

${ }^{30}$ Henderson, Charles 2004: 1 .
} 


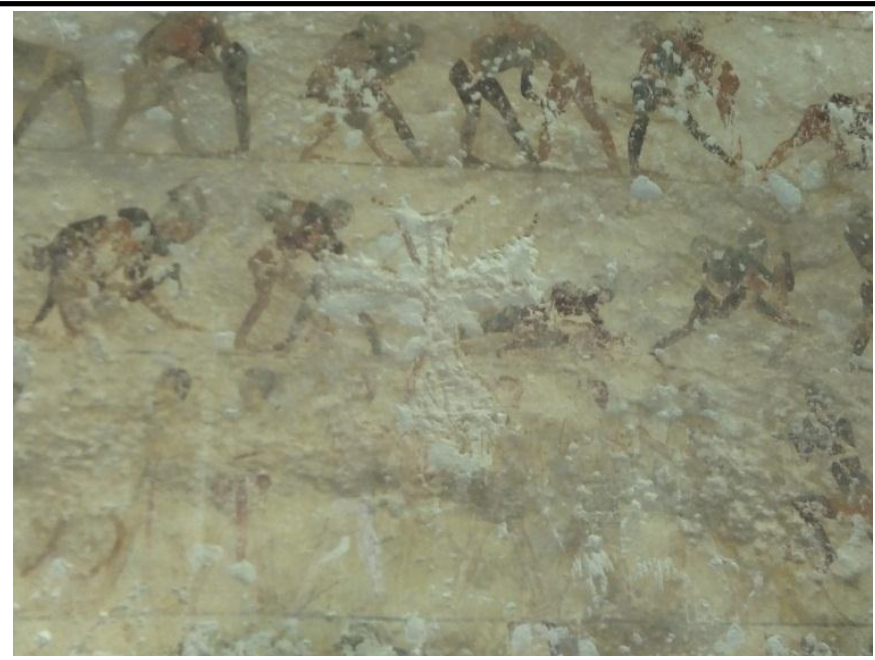

Figure 17. The Maltese cross in tomb 15 at Beni Hassan.

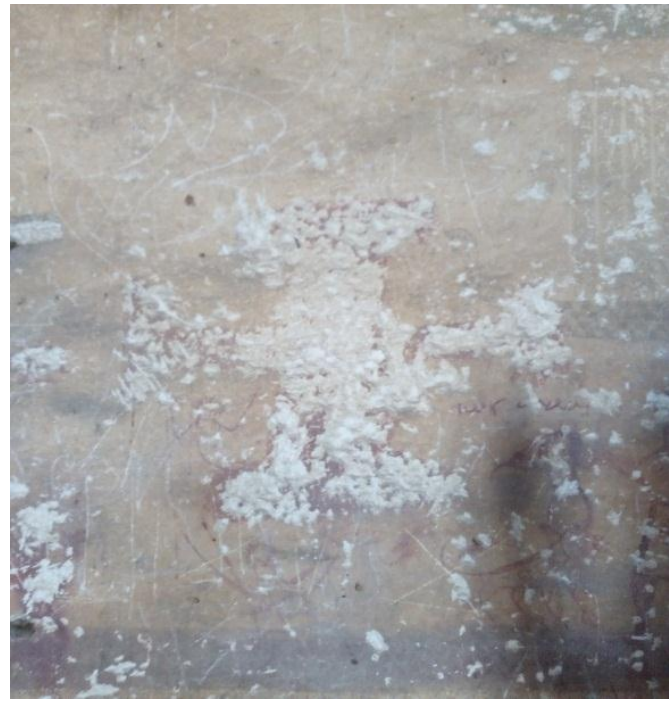

Figure 18. The Maltese cross in tomb 23 at Beni Hassan.

In tomb 33 at Beni Hassan tombs, the Christians decorated the wall with a relatively large Latin cross. They highlight the cross with red ink and in the upper end of the cross what seem to be two small cross are painted on the both sides of the cross. It seems that the lower side of the cross has not been carefully executed, unlike the other three parts. The damaged scenes around the cross cannot be identified (fig. 19). 


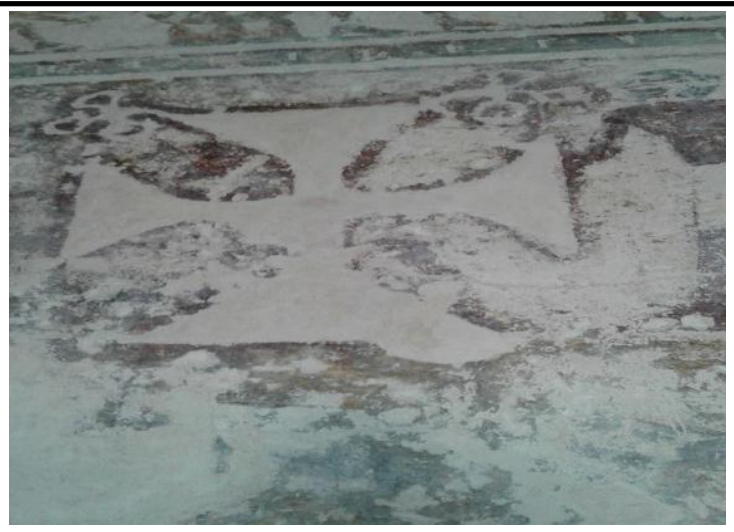

Figure 19. The Maltese cross in tomb 33 at Beni Hassan.

The tomb of Khenumhotep II (No. 2) at Beni Hassan has a small cross, which is painted within the ancient Egyptian scenes without altering or damaging the earlier subject matter. Though small in scale, this cross is executed with care in contrast with the previously discussed examples. Here, the early Christians painted the cross on the south wall, which also received other architectural modification that is represented in the wall niche. It appears that the early Christians were keen to match the colors of the mural modifications they made with those of the earlier Pharaonic representations, thus using the reddish brown color for painting the crosses. This is the same color used for painting the skin of males in ancient Egyptian iconography; the brown color is symbolic of the earth and was often the color of robe of the monks signifying humility and the god's connection with the common place and the ordinary (fig. 20). ${ }^{31}$

\footnotetext{
${ }^{31}$ Henderson, Charles 2004; 1.
} 


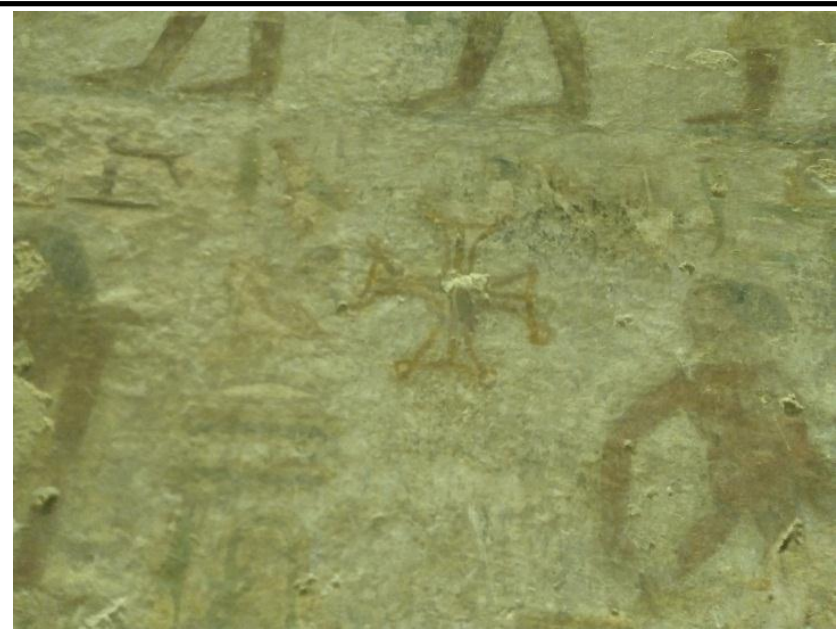

Figure 20. The Maltese cross in the tomb Khenumhotep II at Beni Hassan.

\section{The Greek Cross}

Out of the 10 tombs which were converted into Christian places there are two of tombs at Beni Hassan which have a Greek cross painted on their walls, (tombs 18 and 33) The Greek cross is usually used by the eastern orthodoxy and early Christianity as an emblem of the Christ, all arms of equal length and not much longer than the width. ${ }^{32}$ The transverse branch divides the upright shaft into equal parts and the two arms of the cross are together equal to the upright if a circle divided by two right lines passing through the center these two lines will give you a perfect Greek cross. ${ }^{33}$

The unfinished tomb no. 33 at Beni Hassan has a Greek cross in the upper register of the wall; the cross is painted in black color (fig. 21).

\footnotetext{
${ }^{32}$ Khalaf 2014: 185.

${ }^{33}$ Millington 1851: 375-376.
} 


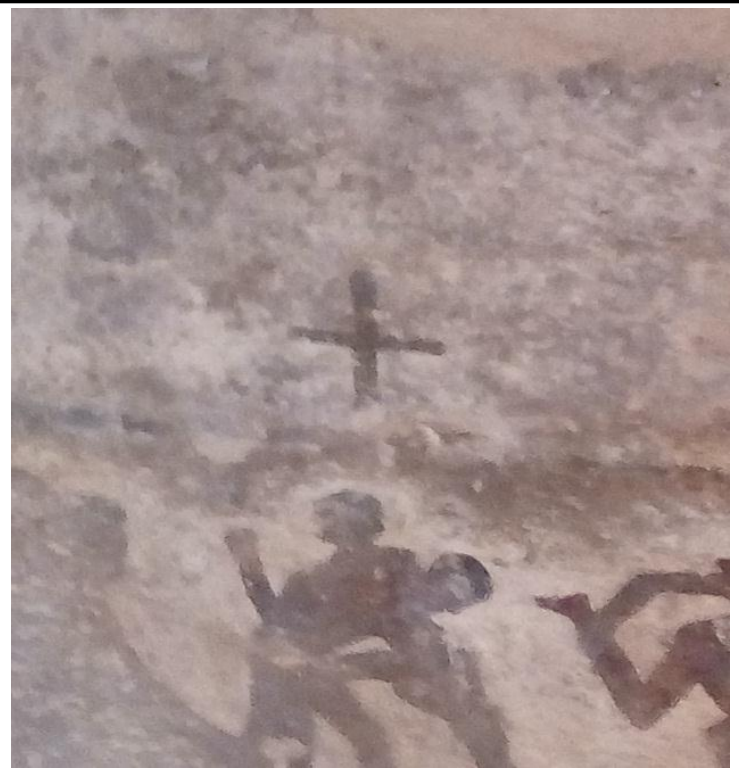

Figure 21. The Greek cross in tomb 33 at Beni Hassan.

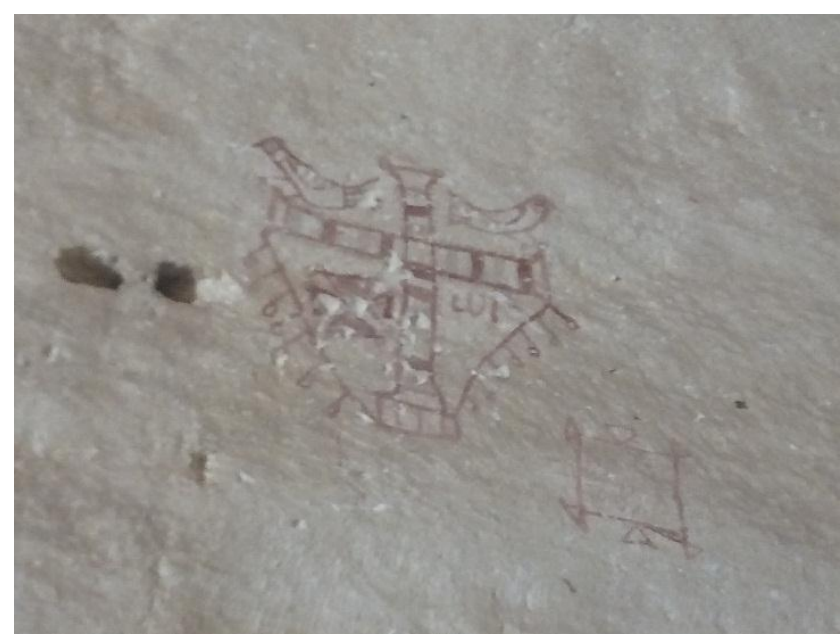

Figure 22. The Greek cross in tomb 18 at Beni Hassan.

Tomb 18 at Beni Hassan has a Greek drawn on the south wall of the tomb in red ink; the cross consists of two rectangles intersecting each other. On both sides of the cross in the upper part there is a dove and two Greek or Coptic letters (alpha and omega). These two letters represent the first and last letter of the Greek or Coptic alphabet, denoting that Jesus the Christ is the beginning and the end (apocalypse $1: 8){ }^{34}$ One of the most interesting representations in worshipping 
places and crypts (dating back to the persecution period is the drawing of dove, which refers to the spread of soul. ${ }^{35}$

\section{The Calvary cross}

It was used as a pagan symbol before the foundation of the Christian church, it is supposed to be the form on which the Christ's suffered, it is usually called Calvary cross. ${ }^{36}$ This is sometimes called the Roman cross, where it takes the shape of a man standing with arms extended. The foot is longer than the upper part or the branches, the shaft is longer than the transverse branch and the foot of the shaft is longer than the upper part. ${ }^{37}$ The Calvary cross is only found in tomb 21 at Beni Hassan, where it is painted on the south wall in red ink. Beside it two small, round openings with unknown function are found. In the lower part we can see a primitive drawing of a person (fig. 23).

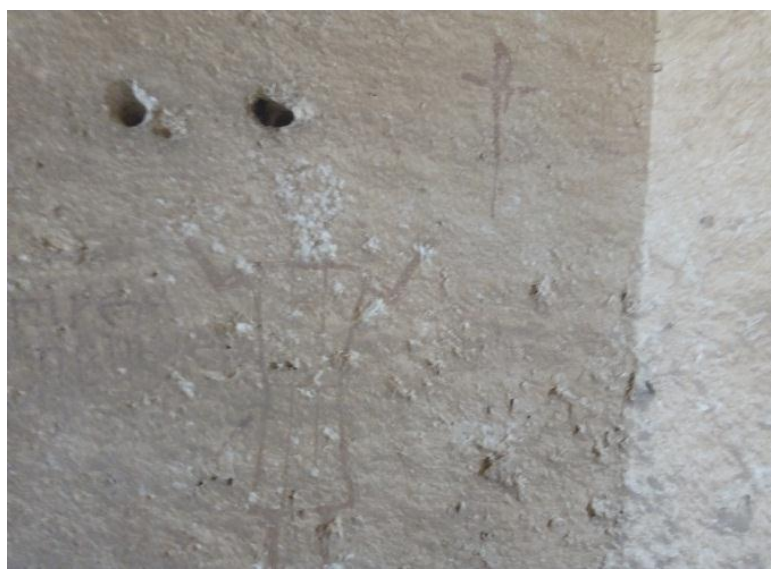

Figure 23. The cavalry cross in tomb 21 at Beni Hassan.

\section{Human Figures:}

Out of 10 tombs at Beni Hassan found two tombs have paintings of human figure Only the lower half of the human figure shown on the south wall in tomb 17 at Beni Hassan can be discerned. The feet and legs are undoubtedly meant to show a human figure. Yet the figure shown on the top of the human figure cannot be identified. The human figure is painted in red ink, yet much of the scene is in a bad state of preservation (fig. 24). The other example of a human representation comes from tomb 21 at Beni Hassan, where one can find a primitive drawing of a person, suggesting that this figure was probably drawn by the worshippers rather than by professional artists. Be that as it may,

\footnotetext{
${ }^{36}$ Khalaf 2014: 190.

${ }^{37}$ Millington 1851: 376.
} 
the figure is shown upraising his arms, perhaps in a praying attitude. On the top right hand side of the figure a Greek cross is shown, perhaps suggesting that he is praying for the cross. Needless to say that modern Christians usually pray in front of a cross. The face of the human figure is completely damaged (fig. 25).

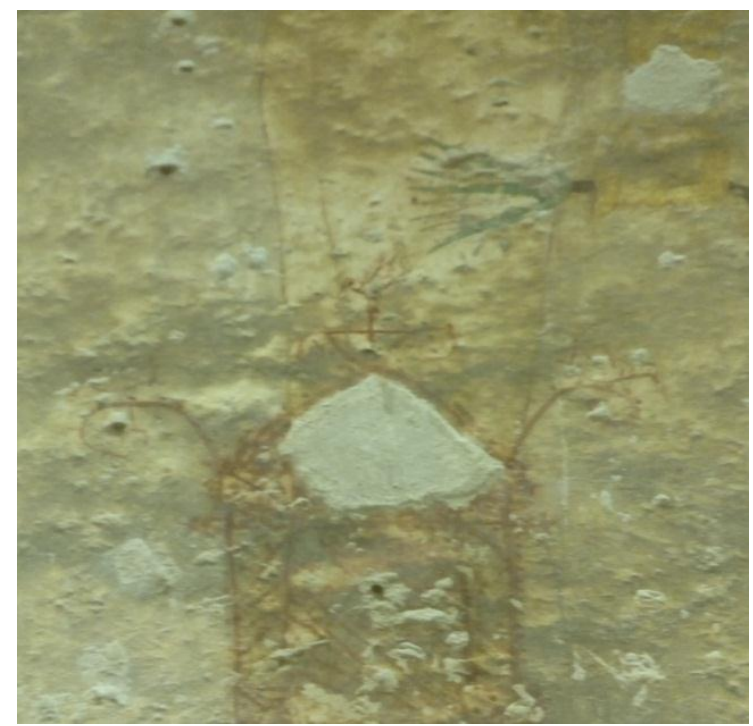

Figure 24. The human figure in tomb 17 at Beni Hassan.

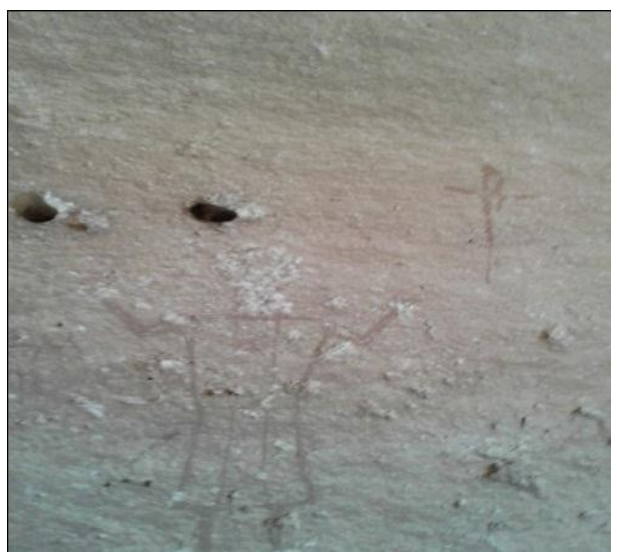

Figure 25. The human figure in tomb 21 at Beni Hassan.

\section{Textual Modifications:}

Having settled ancient Egyptian monuments, the early Christians began to use the temples and tombs for religious, educational, and living purposes. The walls of the converted monuments were used as surfaces for writing Coptic letters and prayers. Out of the 10 tombs converted into Christian structures, there are three at Beni Hassan have Coptic textual (tombs 15, 21, and 23) Some texts only give the names of 
patriarchs, others contain Coptic letters, yet the meaning of some texts and words cannot be explained.

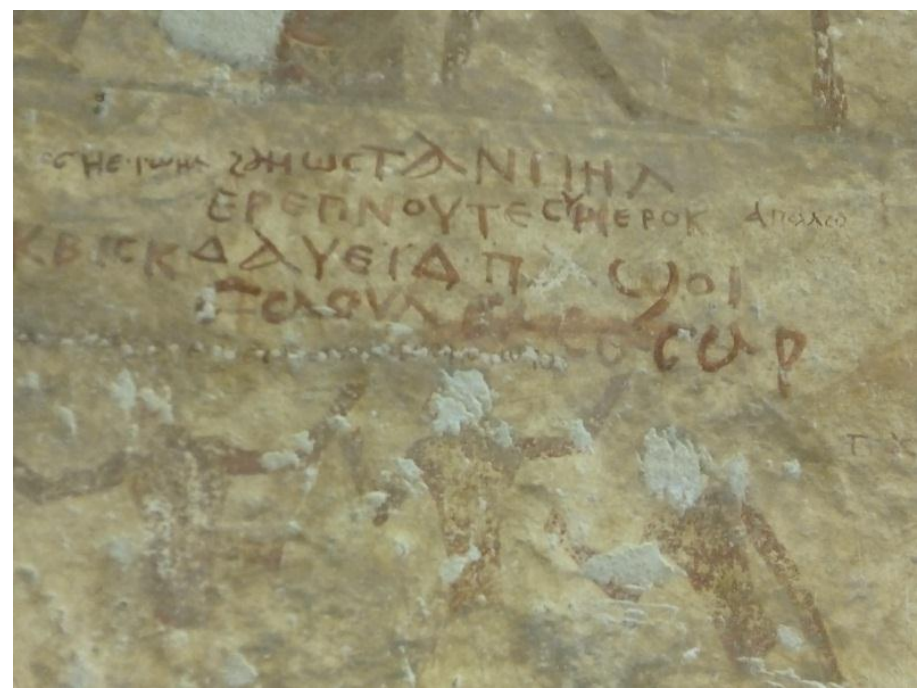

Figure 26. Coptic writings in tomb 15 at Beni Hassan.

The texts were written in red ink on ancient Egyptian scenes, juts under the legs of the fighting soldiers. The texts are written in a chaotic way. As a sacred symbol for the early Christians, a fish is carved beside the Coptic writings. The text reads as:

Help the patriarch Apollo as aided father Jacoup, father Azik, father David, the holy one, and father Mina, for you to holiness. The name of the father, the god of our father Abraham, Harown bless our life, our elder father Apollo, forebode Vekon, Boles, Abraham Jacoup, forebode Nob, Joseph papa Veyown, Aba Hor, Boles, John, Beter, Felobs, anba Nony, anba Sezema, anba Helen, anba Pasenti, anba Felobs). ${ }^{38}$

The tomb of Nouternakhet (Tomb No. 23) at Beni Hassan contains a few words painted in red ink. Apart from the Coptic writings, this tomb lacks decorations. In the middle of Coptic writings a vessel is painted in red ink on the east wall of the tomb. Coptic textual evidence includes (papa Apollo), which means "the father Apollo". ${ }^{39}$ 


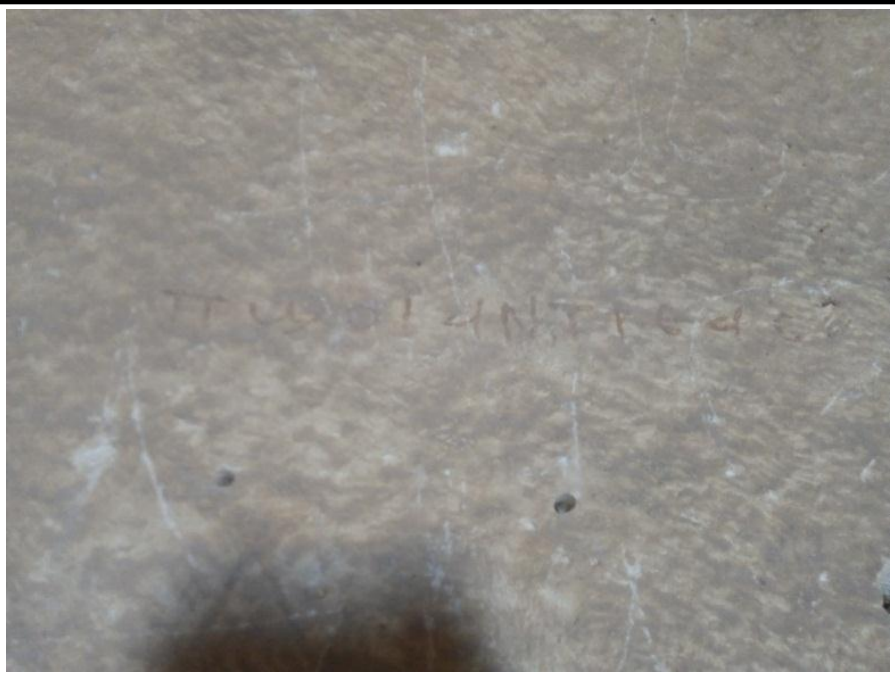

Figure 27. The vessel and Coptic graffiti in tomb 23 at Beni Hassan.

Tomb 21 at Beni Hassan depicts Coptic letters, the meaning of which is not yet clear. There is no doubt that these letters were meaningful for the early Christians, who once settled at this tombs during the fourth century AD. Also unclear are the four small openings carved on the wall just above the Coptic writing (fig. 43).

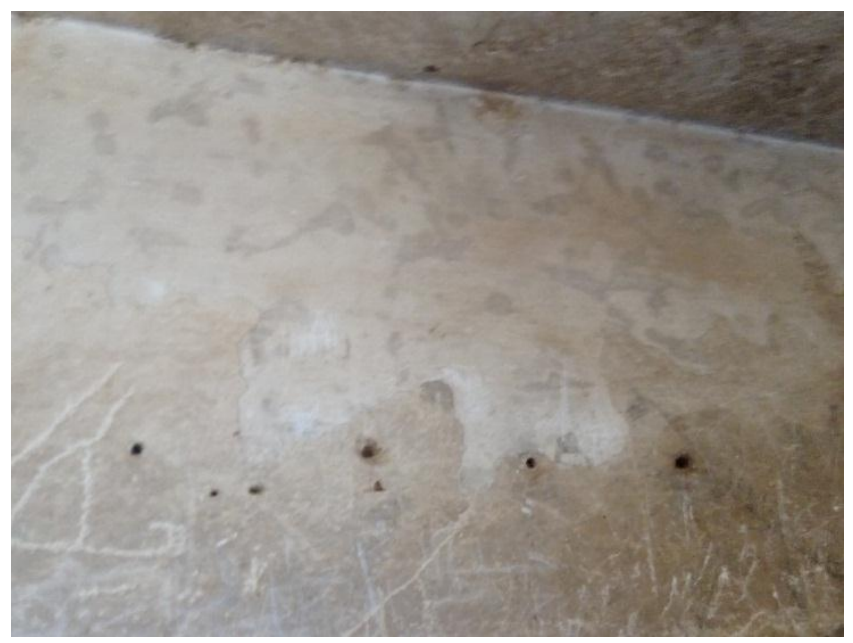

Figure 28. Coptic letters and small openings in tomb 21 at Beni Hassan.

\section{Conclusion}

Many ancient Egyptian tombs at Beni Hassan have been converted into Christian religious, living, and educational purposes. The majority of these tombs were transformed during the fourth $\mathrm{AD}$; Christian modifications included different forms of architectural, mural, and textual changes, which were executed in earlier Egyptian structures. 
Minia Journal of Tourism and Hospitality Research Vol. (6), No. (2/2), December, 2018 By: Faculty of Tourism and Hotels, Minia University

During that time, architectural modifications included the apses, wall niches, also, the early Christians decorated the walls of the converted tombs with plaster or crave or painted different types of crosses and Coptic letters, some of which give the names of patriarchs. 


\section{Bibliography:}

Atiya, A.1991. The Coptic Encyclopedia, New York.

Chennault, R. 2008. Roma without Emperors: The Revival of Senatorial City in the Fourth Century, Michigan.

Grossmann, P. 1980. Reuse of Elephantine II, London

Henderson, Ch. 2004. The Significance of Color in Christian Symbolism, 11

America.

Khalaf, A. 2014. The Woodwork in Minia Churches: Descriptive and Analtic Study, Minia.

Kreider, A. 2007. Violence and Mission in the Fourth and Fifth Centuries: Lessons for Today,

Millington, E.1851. Christian Iconography, London

Morsel, P. (without date). The Worship of the Holy Cross in Saqqara: Archaeological Evidence, Cairo

Newberry, P.1893. Beni Hassan

Pagoulatos, G. (without date). The Destruction and Conversion of Ancient Temples to Christian Churches during Fourth, Fifth and Sixth Churches, Gerasimos.

Tombs, London.

Pyke, G. 1993. The Christian Settlement at Amarna North Tombs, Cairo

Schaff, P. 1882. History of the Christian Church Nicene and Post Nicene Christianity 311-600 AD, Logos.

Weaverdyck, D. 2007. From Pagan to Christian: An Archaeological Study, Minnesota.

Yanney, R.1988. Coptic Church Review, Lebanon.

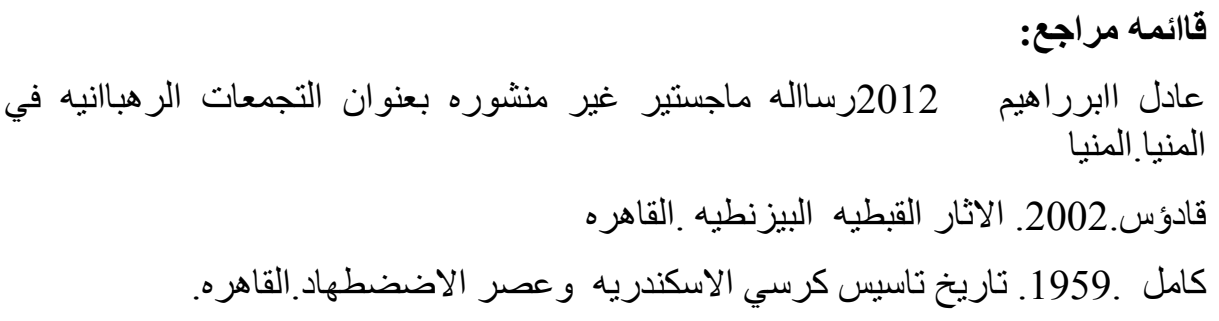

